\title{
ANALISIS PERUBAHAN PENGGUNAAN LAHAN KELAPA SAWIT DARI 2012 - 2016 DI KECAMATAN LANGSA LAMA
}

\author{
(Analysis Of Changes In Palm Oil Land Use From 2012 to 2016 \\ in Langsa Lama District)
}

\author{
Muhammad Husyaini Iqbal ${ }^{1}$, Helmi $^{1}$, Muhammad Rusdi ${ }^{*}$ \\ ${ }^{1}$ Program Studi Ilmu Tanah, Fakultas Pertanian, Universitas Syiah Kuala \\ Email: tanahiqbal@gmail.com
}

\begin{abstract}
Abstrak. Kelapa sawit adalah komoditas pertanian yang populer saat ini. Indonesia sebagai negara pengekspor minyak sawit terbesar di dunia dengan Malaysia. Kondisi daerah yang relatief datar menjadikan Kecamatan Langsa Lama sebagai tempat yang cocok untuk perkebunan kelapa sawit. Kajian perubahan penggunaan lahan berkembang sangat cepat dan menghasilkan banyak pendekatan. Penelitian ini bertujuan untuk menghitung laju perubahan luas lahan kelapa sawit dari tahun 2012- 2016 di Kecamatan Langsa Lama. Metode yang digunakan dalam penelitian ini ada lah metode deskriptif dengan teknik survai. Sedangkan analisis perubahan gunakan rumus/formula untuk menghitung laju perubahan kelapa sawit. Hasil perhitungan analisis di dapat bahwasannya perubahan penggunaan lahan kelapa sawit di Kecamatan Langsa Lama 2012-2016 sebesar 81 Hektar.
\end{abstract}

Kata Kunci: Perubahan lahan, Kelapa Sawit, Langsa Lama

\begin{abstract}
Abstrack. Palm oil is a popular agricultural commodity today. Indonesia is the largest palm oil exporter in the world with Malaysia. Regional conditions that are relatively flat make Langsa Lama District a suitable place for oil palm plantations. The study of land use change developed very quickly and produced many approaches. This study aims to calculate the rate of change in the area of oil palm from 2012-2016 in the District of Langsa Lama. The method used in this study is descriptive method with survey technique. While the change analysis uses a formula / formula to calculate the rate of change of oil palm. The results of the calculation of the analysis can be explained that changes in the use of oil palm in the District of Langsa Lama 2012-2016 amounted to 81 hectares.
\end{abstract}

Keyword: Land change, Oil Palm, Langsa Lama

\section{PENDAHULUAN}

Tanaman kelapa sawit (Elaeis guineensis Jacq) merupakan tumbuhan tropis golongan palm yang termasuk tanaman tahunan. Tanaman Kelapa Sawit berasal dari Negara Afrika Barat. Tanaman ini dapat tumbuh subur di Indonesia, Malaysia, Thailand, dan Papua Nugini. Kelapa Sawit merupakan tanaman yang sangat penting bagi pembangunan nasional karena dapat menyerap lapangan tenaga kerja yang lebih besar dan sebagai sumber devisa negara. Tanaman ini mulai diusahakan dan dibudidayakan secara komersial pada tahun 1991. Orang yang pertama kali merintis usaha perkebunan kelapa sawit di 
Indonesia adalah Andrian Hallet seorang yang berkebangsaan Belgia yang telah belajar banyak tentang perkebunan kelapa sawit di Afrika (Masykur, 2013).

Pola perubahan penggunaan lahan cenderung dinamis dan memiliki kecepatan perubahan yang berbeda di setiap wilayah. Hal ini dikarenakan perubahan yang terjadi sangat tergantung pada faktor pendorongnya. Faktor tersebut dominan terbagi dalam dua kategori, yaitu kondisi bio-fisik dan kondisi sosial-ekonomi. Faktor bio-fisik melibatkan karakteristik dan proses ekologi alamiah seperti iklim, topografi, jenis tanah, proses geomorfik dan ketersediaan sumberdaya alam. Faktor sosial-ekonomi mencakup demografi, sosial, ekonomi, politik dan kelembagaan, serta proses-proses yang terjadi didalamnya seperti perubahan penduduk, perubahan struktur industri, teknologi, kebijakan, dan sebagainya. Faktor bio-fisik tidak mempengaruhi secara langsung, kebanyakan hanya menyebabkan terjadinya perubahan pada tutupan lahan atau mempengaruhi keputusan pengelolaan terhadap lahan tersebut yang merupakan aktivitas manusia (Mas, 2004)

(Verburg, 2004) Menyatakan bahwa dalam pemodelan perubahan penggunaan lahan ini paling tidak terdapat enam aspek yang harus diperhatikan, yaitu: cakupan analisis, dinamika silang-skala (cross-scale), factor pemicu, interaksi spasial dan dampak kedekatan lokasi, dinamika antar waktu dan proses penggabungan. Keenam aspek tersebut merupakan topik utama dalam kajian perubahan penggunaan lahan (Sitorus, 2012).

Dikutip dari Jurnal Bumi (2017), mengabarkan bahwa pada tahun 2016 Indonesia menghasilkan 36 juta ton kelapa sawit yang menempatkan negara Indonesia menjadi penghasil kelapa sawit terbesar di dunia yang berarti Indonesia menempati peringkat pertama menggeser Malaysia sebagai penghasil kelapa sawit terbesar dunia.

Kecamatan Langsa Lama merupakan salah satu dari 5 Kecamatan yang ada di Kota Langsa. Secara administrasi kecamatan Langsa Lama berbatasan langsung dengan Kabupaten Aceh Timur. Berdasarkan data BPS Kota Langsa Kecamatan Langsa Lama memiliki lahan sawit yang cukup luas dan terus mengalami peningkatan setiap tahunnya.

\section{METODE PENELITIAN}

Kajian ini dilakukan di Kecamatan Langsa Lama yang terletak di Kota Langsa dapat dilihat pada Gambar 1. Penelitian ini dilakukan pada bulan MeiSeptember 2017 dan pengelolaan data secara spasial dilakukan di Laboratorium Pengindraan Jauh dan Kartografi Fakultas Pertanian Universitas Syiah Kuala. 


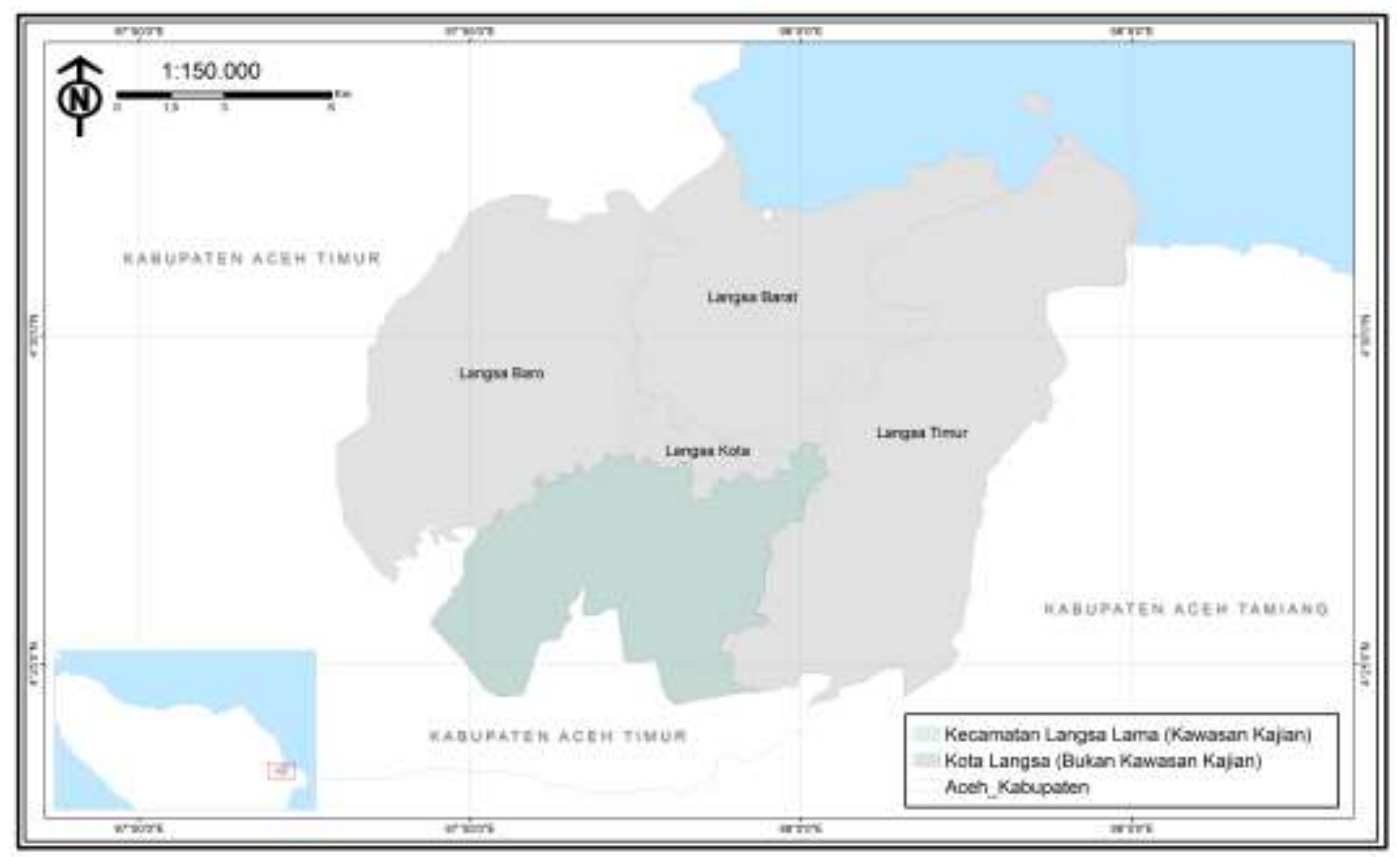

Gambar 1. Wilayah Kajian Penelitian

Perubahan luas lahan kelapa sawit dianalsis mengunakan sistem informasi geografis SIG dengan metode reclassiffy. Dimana citra dalam bentuk jpeg di georeferencing yang bertujuan untuk mengubah menjadi shapefile. Kemudian dilakukan digitasi untuk melihat pengunaan lahan yang telah mengalami perubahan dan kemudian dilakukan reclassiffy untuk menghitung laju perubahan luas lahan kelapa sawit sesuai pada attribute table. Selanjutnya gunakan rumus/formula untuk menghitung kelas laju perubahan kelapa sawit di Kecamatan Langsa Lama dari tahun 2012 - 2016.

\section{HASIL DAN PEMBAHASAN}

Laju perubahan lahan adalah angka yang menunjukkan persentase perubahan penggunaan lahan dalam jangka waktu tertentu. Perkebunan kelapa sawit di Indonesia terus mengalami peningkatan. Sejak dikembangkannya tanaman kelapa sawit di Indonesia pada tahun 60-an, luas areal perkebunan kelapa sawit mengalami perkembangan yang sangat pesat. Bila pada 1967 Indonesia hanya memiliki areal perkebunan kelapa sawit seluas 105.808 hektar, pada 1997 telah membengkak menjadi 2,5 juta hektar, hal ini yang memungkinkan perkembangan luas lahan kelapa sawit di Kecamatan Langsa Lama ikut meningkat. 


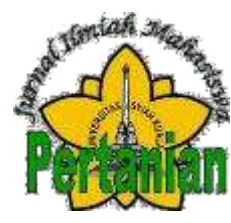

Hasil digitasi citra satelit 2012 mendapati luas lahan kelapa sawit Kecamatan Langsa Lama sebesar 2.163 Hektare, perubahan luas terjadi pada lahan kelapa sawit tahun 2016, hasil digitasi citra satelit tahun 2012 dapat dilihat pada Gambar 12.

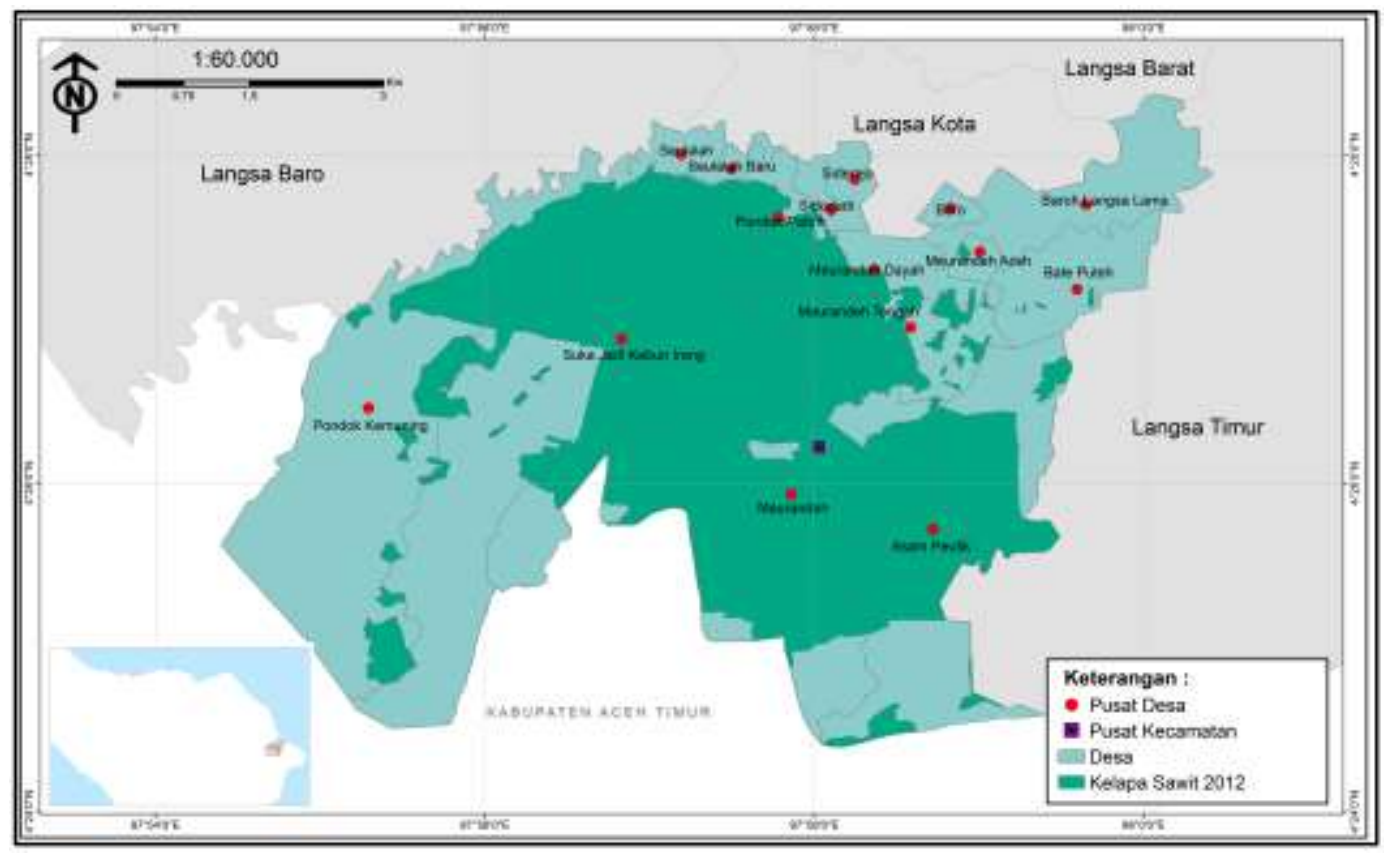

Gambar 2. Lahan Kelapa Sawit Tahun 2012

Hasil digitasi citra satelit 2016 mendapati luas lahan kelapa sawit Kecamatan Langsa Lama sebesar 2.244 Hektare. Hasil digitasi citra satelit tahun 2016 dapat dilihat pada Gambar 3. Luas sebaran penggunaan lahan kelapa sawit tahun 2016 terbesar ada di Desa Suka Jadi Kebun Ireng sebesar 608 dan Desa Baroh Langsa Lama memiliki wilayah terkecil yaitu sebesar 2 Hektare kondisi terjadi perubahan luas pada 2 Desa ini dan juga terjadi perubahan luas luasan pertahun pada Desa lain.

Peta perubahan penggunaan lahan menunjukan perubahan penggunaan lahan di Kecamatan Langsa Lama. Terlihat dari perubahan warna yang terjadi yang menunjukan bahwa peta tersebut mengalami perubahan. Berdasarkan analisis spasial di atas dapat di dilihat luas per Desa yang mengalami penggunaan lahan kelapa sawit di Kecamatan Langsa Lama tahun 2012 - 2016.

Pesebaran penggunaan lahan kelapa sawit di Kecamatan Langsa Lama dapat dilihat ada 10 Desa yang mengalami penggunaan lahan kelapa sawit pada tahun 2016 yaitu Asam Peutik, Baroh Langsa Lama, Bate Puteh, Meurandeh Dayah, Meurandeh Tengah, Meurandeh, Pondok Pabrik, Sidodadi, Pondok Kemuning, Suka Jadi Kebun Ireng. Bila dikaitkan dalam adminitrasi dilihat Desa yang paling banyak mengalami perubahan luas yaitu Desa Meurandeh Dayah dari 49 hektare menjadi 106 hektare perubahan luas lahan kelapa sawit pada 10 Desa dapat dilihat pada Tabel 1. 


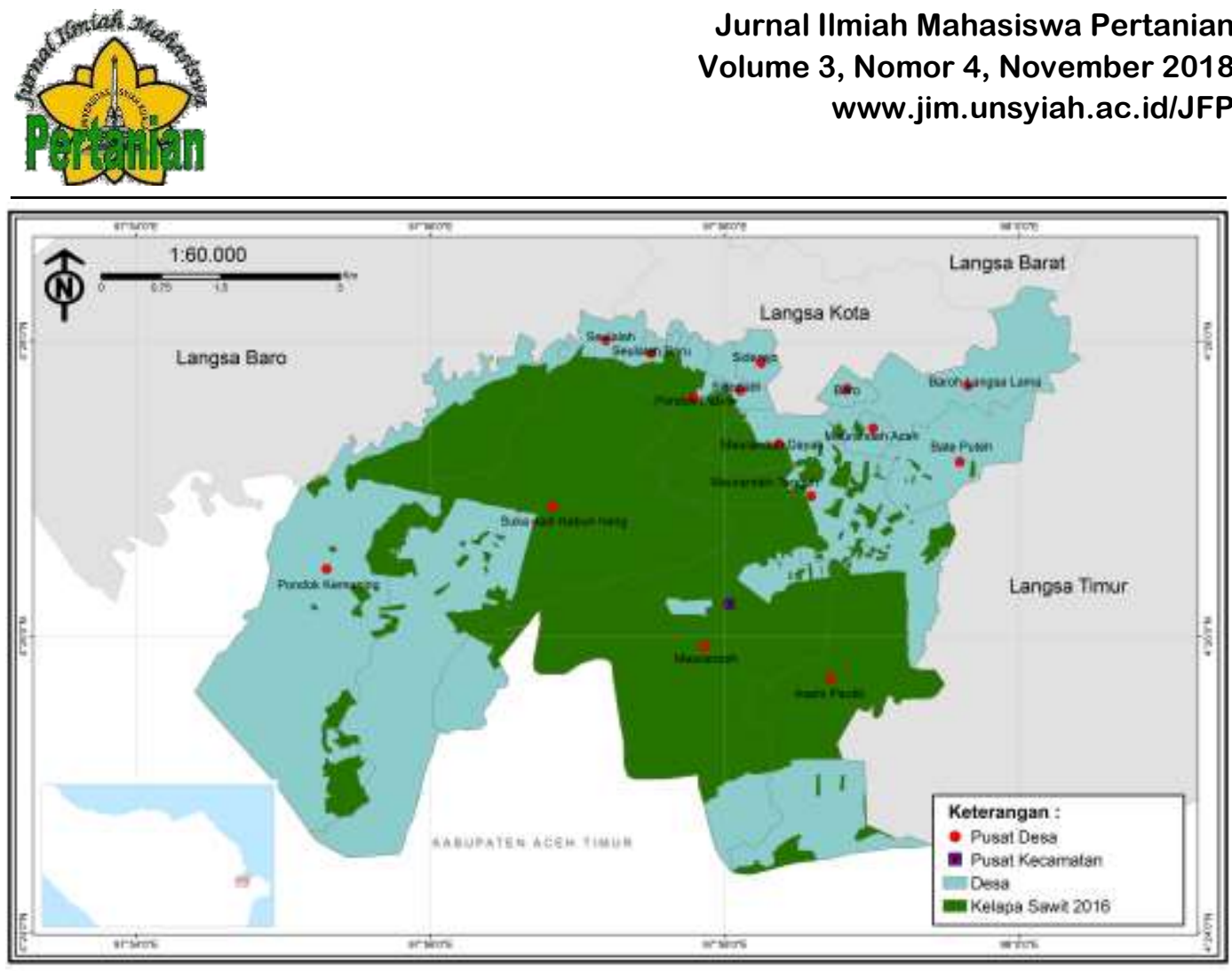

Gambar 3. Lahan Kelapa Sawit 2016

Tabel 1. Luas Lahan Kelapa Sawit per Desa di Kecamatan Langsa Lama

\begin{tabular}{lrr}
\hline Desa & Tahun / Luas (Ha) \\
\cline { 2 - 3 } & 2012 & 2016 \\
\hline Asam Peutik & 325 & 333 \\
Baroh Langsa Lama & 1 & 2 \\
Bate Puteh & 2 & 3 \\
Meurandeh Dayah & 49 & 106 \\
Meurandeh Tengah & 103 & 104 \\
Meurandeh & 727 & 730 \\
Pondok Pabrik & 106 & 109 \\
Pondok Kemuning & 245 & 248 \\
Suka Jadi Kebun Ireng & 605 & 608 \\
Sidodadi & - & 1 \\
\hline Jumlah & 2.163 & 2.244
\end{tabular}

Analisis Perubahan Luas Lahan Kelapa Sawit dari 2012-2016 di Kecamatan Langsa Lama 
Analisis perubahan luas lahan kelapa sawit di hitung menggunakan rumus yaitu sebagai berikut :

$$
V: \frac{L}{t}
$$

Berdasarkan rumus analisis diatas maka dapat dilihat perubahan luas lahan kelapa sawit sebesar $20.25 \mathrm{Ha} /$ Tahun. Dimana secara rinci hasil perubahan luas lahan kelapa sawit adalah :

$$
\begin{aligned}
& V: \frac{81 \mathrm{Ha}}{4 \text { Tahun }} \\
& V=20,25 \mathrm{Ha} / \text { Tahun }
\end{aligned}
$$

Dari hasil analisis perubahan luas lahan kelapa sawit didapat 20,25 $\mathrm{Ha}$ /Tahun pada laju perubahan luas lahan kelapa sawit tahun 2012 - 2016 di Kecamatan Langsa Lama.

\section{KESIMPULAN}

Berdasarkan hasil penelitian yang telah dilakukan, dapat disimpulan bahwa telah terjadi perubahan lahan kelapa sawit tahun 2012 - 2016 di dapat perubahan luas lahan sebesar 81 Hektar (20.25 Ha/Tahun).

\section{DAFTAR PUSTAKA}

Jurnal Bumi. Berita : Top 10 Negara Penghasil Sawit Terbesar. https://jurnalbumi.com/negara-penghasil-sawit. Diakses 14 Juli 2018.

Masykur. 2013. Pengembangan Industri Kelapa Sawit Sebagai Penghasil Energi Bahan Bakar Alternatif dan Mengurangi Pemanasan Global (Studi di Riau Sebagai Penghasil Kelapa Sawit Terbesar di Indonesia)

Mas JF, Puig H, Palacio JL and Sosa-Lopez A. 2004. Modelling Deforestation using GIS and Artificial Neural Network. Environmental Modelling \& Software 19: 461-471

Sitorus, S. R. P. 2012. Analisis Pola Perubahan Penggunaan Lahan Dan Perkembangan Wilayah Di Kota Bekasi, Provinsi Jawa Barat. 14, 21-28.

Verburg, P. H., P.P. Schot, M.J. Dijst, and A. Veldkamp. 2004. Land use change modelling: current practice and research priorities. 